\title{
Effect of Filling Media on the Quality Characteristics of Acetes Balls during Retort Processed
}

\author{
S. M. Shaikh ${ }^{1 *}$, V. R. Joshi ${ }^{1}$, A. U. Pagarkar ${ }^{1}$, G. N. Kulkarni ${ }^{1}$ and Abhay Kumar ${ }^{2}$ \\ ${ }^{1}$ College of Fisheries, Shirgaon, Ratnagiri, Maharashtra (India) \\ ${ }^{2}$ ICAR-CIFT of Mumbai Research Center, Vashi, Navi Mumbai, India \\ *Corresponding author
}

\section{A B S T R A C T}

\begin{tabular}{|l|}
\hline K e y w o r d s \\
Acetes product, \\
$\begin{array}{l}\text { Acetes ball in curry, } \\
\text { Retort pouch, } \mathrm{F}_{0} \\
\text { values, Heat } \\
\text { processing }\end{array}$ \\
\hline Article Info \\
\hline $\begin{array}{l}\text { Accepted: } \\
\text { 16 November } 2020 \\
\text { Available Online: } \\
\text { 10 December } 2020\end{array}$
\end{tabular}

\section{Introduction}

Non-penaeid prawns constitute one of the important fishery resources in India and this resource is very characteristic of the north west coast, particularly in Gujarat and Maharashtra accounting to $90 \%$ of their total landings in the Country. During the year 2017-18, about 136123 tonnes of non-penaeid prawns were landed along the Indian coast and out of this, 63719 tonnes was landed along the coast of Maharashtra. In the year 2017, the total marine fish landing of Maharashtra state has been provisionally estimated as 475668 tones. (FSI, 2019).
In India, most of the Acetes sp. locally known as Jawala (a small size shrimp growing to a maximum length of $4 \mathrm{~cm}$ and weighing about $0.5 \mathrm{~g}$ ) is landed along the North West coast, i.e. in the state of Gujarat and Maharashtra (Zynudheen et al., 2004). Locally people use the Jawala either in fresh or dried form for the preparation of day-to-day food dishes.

However, during the monsoon season, mostly Jawala is preferred in fresh form. Previously, attempts were made to prepare acetes powder (Mulbagal et al., 1980; Jagushte, 1989) and separate flesh from acetes (Garg et al., 1977; Patil, 2000). Authors viz., Jagushete (1989) 
have also attempted products such as sevu, noodles etc. using powdered acetes.

As per the prevailing practice, jawala is sundried on the beach and sold in the dried form for human consumption in the domestic market. However, functional properties of protein in fresh acetes are lost after it is dried. This happens due to protein denaturation due to heating during drying. Hence, this necessitates the use of acetes in fresh condition so as to utilize all the functional properties of acetes protein to the maximum extent.

Emulsion type fish paste products is traditional products of Japan. These products are relished for high gel strength, white colour and bland taste characteristics. Several products have been prepared from fresh acetes meat such as acetes sausage (Nagothkar, 2013), acetes sandwich (Sonavane, 2014), acetes chikuwa, acetes steamed wada, acetes ball in curry etc (Joshi, 2014). These products are generally consumed immediately after preparation and can also be stored for short term at 0 to $2^{0} \mathrm{C}$ or for long term storage, these are frozen and held at $-20^{0} \mathrm{C}$. For storage at room temperature, these products have to be processed at $121.2^{0} \mathrm{C}$ for $4 \mathrm{~min}$ in retort pouch to achieve better sensory quality as reported by Shaikh et al., (2017). So far, no work has been carried out on the effect of filling media on acetes balls subjected to thermal processing. Therefore, the present study was undertaken to study the effect of filling media on acetes ball subjected to thermal processing.

\section{Materials and Methods}

Fresh Acetes sp. was procured from landing center at Mumbai was immediately frozen, brought and stored at $-20^{\circ} \mathrm{C}$ in $\mathrm{M} / \mathrm{S}$. Naik Ice and Cold storage, Ratnagiri, Maharashtra (India). Before use, whole acetes was thawed, weighed and subjected to shell separation by putting in meat separator to separate shell and meat. The separated meat was subjected to squeezing with thin synthetic cloth to remove excess liquid. Frozen surimi prepared from acetes meat and pink perch (Nemipterus japonicas) procured from a commercial factory was thawed before use. Acetes ball and curry paste was prepared as per the recipe by Joshi (2014) in Table 1 and 2. Oil was heated in pan and onion was added, fried to brown colour and then made into paste. In a separate pan, oil was heated and finely-cut tomato was added, fried and then made into paste. In another pan, oil was heated and garlic, ginger, coriander seed powder, garam masala and salt were added and fried. To this pan onion paste, red chilly powder and turmeric were added and the mixture was cooked along with the tomato paste. The above curry paste was mixed with oil and heated for $2 \mathrm{~min}$ and then same paste was mixed with water in 2:1 ratio and boiled for 5 min. Acetes ball was prepared according to the recipe of Joshi (2014) in Table 2. Acetes meat and surimi were added in silent cutter and ground well for $2 \mathrm{~min}$. Salt was added and ground for another $2 \mathrm{~min}$. Other ingredients viz., starch, red chilly powder, coriander seed powder, garam masala, coriander leaves paste, ginger-garlic paste were added and mixed thoroughly by continuous grinding. $10 \mathrm{~g}$ of paste was made into balls and subjected to steaming at $\left(100^{\circ} \mathrm{C}\right.$ $0 \mathrm{psi}$ ) for $30 \mathrm{~min}$. The acetes ball and liquid curry were prepared and used for further studies. The pasteurized $\left(100^{\circ} \mathrm{C}\right)$ acetes balls for $30 \mathrm{~min}$ were kept as a control.

The above procedure was repeated for preparation of plain acetes ball (Table 3) except for addition of spice mixture and paste (Joshi, 2014). Acetes meat and surimi were ground well in silent cutter for $2 \mathrm{~min}$, then salt was added and grinding was continued for 2 min. Later starch was added and grinding 
was continued. Acetes ball paste weighing10 $\mathrm{g}$ was molded into balls.

Acetes balls were steamed at $100^{0} \mathrm{C}(0 \mathrm{psi})$ for $30 \mathrm{~min}$, packed in retort pouch along with curry (acetes ball $100 \mathrm{~g}$ and curry $150 \mathrm{~g}$ ) and without curry, sealed, washed, stacked in retort and subjected to thermal processing at a retort temperature of $121.2^{\circ} \mathrm{C}$ for $4 \mathrm{~min}$ duration. A process duration of 4 minutes was selected based on the previous study conducted for attaining a complete sterility for the product (Shaikh et al., 2017). Steam was then shut off and simultaneously air and water were pumped inside the retort to maintain the internal pressure of 25 psi and cooling was continued inside the retort till the temperature at cold spot of the product inside the pouch reached $30^{\circ} \mathrm{C}$. Later, the pouches were wiped dry and stored until further use. Mention the final four lots of samples prepared with their expansions for further clarification. Abbreviations of the samples can be used when mentioning later in the text.

\section{Analytical method}

Commercial sterility test was conducted as per the methodology given in IS: 2168 (1971). Biochemical parameters such as $\mathrm{pH}$ and moisture (AOAC, 2005), physical properties viz., gel strength and expressible water (Suzuki, 1981) and organoleptic indices (ISI, 1975) based on the characteristics viz., appearance, colour, taste and texture by 10 trained panelists were evaluated.

\section{Results and Discussion}

For commercial sterilization of low acid canned foods (LACF), it is mandatory to process all $\mathrm{LACF}$ to an $\mathrm{F}_{0}$ value not less than 3 min. In practice, the process is usually higher than this minimum $\mathrm{F}_{0}$ of 3 min owing to some probability of under process and spoilage from heat tolerable organisms.
Depending upon the product and the climatic conditions of storage, a typical $F_{0}$ value used operationally for fish and meat products generally varies in the range of 5-20 min (Bratt, 1995; Pflug and Christensen, 1980). However, Saralaya et al., (1978) suggested that thermal processes equivalent to $\mathrm{F}_{0}=5.2$ may be taken as minimum and those with $\mathrm{F}_{0}=12$ as maximum for canned fish sausages prepared under hygienic conditions using good quality raw materials. As per the suggestions by Shaikh et al., (2017) acetes ball in curry product processed at $4 \mathrm{~min}$ at about $121.2^{0} \mathrm{C}$ gave better results, which was chosen for heat penetration studies to assess the thermal process value in the present study.

Spice mixture acetes balls-with-curry (SABWC), spice mixture acetes ballswithout-curry (SABWOC), plain acetes ballswith-curry (PABWC) and plain acetes-ballswithout curry (PABWOC).

The come-up time (CUT) of SABWC, SABWOC, PABWC and PABWOC products packed in retort pouch to achieve a processing temperature of $121.2^{0} \mathrm{C}$ was found to be 38 , 73,39 and 72 min respectively, along with 4 min of processing periods for all four types. Further, a cooling period of 24, 18, 23 and 19 min were noticed for respective four products. The total process period (CUT $+\mathrm{PP})$ was determined to be $42,77,43$ and $84 \mathrm{~min}$ processed at $121.2^{\circ} \mathrm{C}$ for $\mathrm{SABWC}$, SABWOC, PABWC and PABWOC, respectively with the corresponding $\mathrm{F}_{0}$ value of 10.65, 12.68, 10.61 and 13.05 min (Fig. 1, 2, 3 and 4), respectively. The total process value was considered based on the minimum requirement of destruction of Clostridium botulinum spores and the maximum value considering heat resistance of prevalent high heat resistant organisms and the retention of nutritive value and better organoleptic qualities of the four types of acetes ball products. 
Saralaya et al., (1978) reported that among the factors that influence the rate of heat penetration, filling medium seems to be the most significant. This is to be expected, since heat is conveyed through the liquid medium at a faster rate by convection, even though within the sausage pieces heat transfer is by conduction. The brine and oil filled cans had a heating rate faster by 50 percent or more than dry packed cans.

Among the four $\mathrm{F}_{0}$ values of the acetes balls (Sea food packed in retort pouch), few scientists have reported $\mathrm{F}_{0}$ values (processed at $121^{\circ} \mathrm{C}$ ) of 8.5 for fish curry (Gopal et al., 1998), 8.15 for seer fish moilee (Manju et al., 2004), 8 for mackerel curry (Ravishankar et al., 2008) 12.1 for goat meat curry (Rajkumar et al., 2010), 8.5 for mahseer curry (Bindu et al., 2011) and 6 for fish ball in curry processed at $115^{\circ} \mathrm{C}$ for (George et al., 2015a). A higher value of $F_{0}$ was noted in the present study when compared to previous reports which could be due to the variation in texture of fish, pack weight, solid to liquid ratio. In the present study, texture of acetes ball in curry which is a gel product may be entirely different from that of cooked fish flesh as reported by above authors. As compared to goat meat curry, $\mathrm{F}_{0}$ value in present study was found to be lower which may due to the difference in the composition and generally observed hard texture of cooked goat meat in comparison to acetes ball in curry. In the present study unlike that of fish ball in curry (George et al., 2015a) higher $\mathrm{F}_{0}$ value has been noted which can be due to variation in texture of fish ball, pack weight, solid to liquid ratio and process value $\left(115^{\circ} \mathrm{C}\right.$ as against $121.2^{0} \mathrm{C}$ ).

In case of effect of filling media, it was found that the textural scores (Fig. 5) of (PABWOC) were higher $(p<0.05)$ as compared to other samples. Similarly, folding test grade of both control is without thermal processing and
PABWOC was found to be higher (A) accompanied by lower expressible water percentage $(4.1 \%)$ as compared to other three products. However, the colour and taste scores of PABWOC were lower as compared to PABWC, SABWOC and SABWC. Similar observations were made by George et al., (2015b) i.e. plain fish balls without curry had higher textural scores along with higher folding test grades and lower expressible water percentage as compared to others. However, Runglerdkriangkrai et al., (2006) reported a decrease in textural scores of fish balls processed at $116^{\circ} \mathrm{C}$ for $30 \mathrm{~min}$ as compared to steamed (unsterilized) samples. Saralaya et al., (1978) reported that the textural score of canned pink perch fish sausage (in natural casing) had lower values, which indicated fair quality. The difference in this and the present study may be due to the difference in preliminary treatment. In the former study, leakage of components could have occurred from the fish sausage paste stuffed in natural casing which is porous in nature to the water, while pasteurizing in hot water i.e. at $80^{\circ} \mathrm{C}$ for $20 \mathrm{~min}$. Also difference in the composition of the raw material, ingredient and ingredient ratio might have contributed to the variation in the textural scores. In the present study, the acetes balls were steamed at $100^{\circ} \mathrm{C}$ for $30 \mathrm{~min}$ and had high gel strength i.e. high folding test grade. This higher initial gel strength formed in the acetes balls might have resulted in retention of higher gel strength during thermal processing (at $121.2^{0} \mathrm{C}$ ). For this reason, traditional Japanese style fish paste products such as kamaboko etc. are steamed at $100^{\circ} \mathrm{C}$ for different duration depending on size (Suzuki, 1981). However, in the present study the textural scores of acetes balls subjected to thermal processing were slightly lower than those of steamed $\left(100^{\circ} \mathrm{C}, 0\right.$ psi) acetes balls. This may be attributed to the loss of total SH plus SS groups which occur during oxidation to cysteic acid or splitting to hydrogen 
sulphide (Nakai and Li-Chan, 1988; Yamazawa et al., 1979). $\mathrm{H}_{2} \mathrm{~S}$ formation originated from the free reacting $\mathrm{SH}$ groups of actomyosin starts at about $80^{\circ} \mathrm{C}$ and increases exponentially with rising temperature (Hamm and Hofmann, 1965)The above factor responsible for gel strength reduction due to thermal processing may not be operational in PABWOC and SABWOC in which low moisture level exists due to the entrapment within the gel matrix already formed prior to packing and processing.

Table.1 Recipe of Curry Paste for Liquid Curry

\begin{tabular}{|c|l|c|}
\hline Sr. No. & \multicolumn{1}{|c|}{ Ingredients } & Quantity $(\mathbf{g} / \mathbf{1 0 0 g})$ \\
\hline $\mathbf{1}$ & Onion paste & 13.6 \\
\hline $\mathbf{2}$ & Tomato paste & 5.3 \\
\hline $\mathbf{3}$ & Garlic paste & 0.5 \\
\hline $\mathbf{4}$ & Chilly powder & .234 \\
\hline $\mathbf{5}$ & Turmeric powder & .05 \\
\hline $\mathbf{6}$ & Coriander seed powder & .072 \\
\hline $\mathbf{7}$ & Spice mixture & .062 \\
\hline $\mathbf{8}$ & Green chili paste & .29 \\
\hline $\mathbf{9}$ & Coriander leaves paste & .144 \\
\hline $\mathbf{1 0}$ & Ginger paste & .12 \\
\hline $\mathbf{1 1}$ & Salt & .33 \\
\hline $\mathbf{1 2}$ & Total curry paste & 21.202 \\
\hline $\mathbf{1 3}$ & Remaining part water & 9.0 \\
\hline $\mathbf{1 4}$ & Total & 30.20 \\
\hline
\end{tabular}

Table.2 Recipe of Acetes Balls

\begin{tabular}{|c|l|c|}
\hline Sr. No. & \multicolumn{1}{|c|}{ Ingredients } & Quantity (\%) \\
\hline $\mathbf{1}$ & Acetes mince & 57.91 \\
\hline $\mathbf{2}$ & Surimi & 19.30 \\
\hline $\mathbf{3}$ & Starch & 11.58 \\
\hline $\mathbf{4}$ & Salt & 1.54 \\
\hline $\mathbf{5}$ & Garlic paste & \\
\hline $\mathbf{6}$ & Red chili powder $^{*}$ & 3.08 \\
\hline $\mathbf{7}$ & Coriander seed powder & 1.54 \\
\hline $\mathbf{8}$ & Spice mixture & 1.54 \\
\hline $\mathbf{9}$ & Coriander leaves paste* & 3.08 \\
\hline $\mathbf{1 0}$ & Ginger paste & 0.75 \\
\hline $\mathbf{1 1}$ & Total & 0.38 \\
\hline
\end{tabular}

Table.3 Recipe of plain acetes balls

\begin{tabular}{|c|l|c|}
\hline Sr. No. & Acetes Ball Paste & Composition (\%) \\
\hline $\mathbf{1}$ & Acetes mince & 57.91 \\
\hline $\mathbf{2}$ & Surimi & 19.30 \\
\hline $\mathbf{3}$ & Starch & 11.58 \\
\hline $\mathbf{4}$ & Salt & 1.54 \\
\hline
\end{tabular}


Table.4 Effect of filling media on the biochemical and physical parameters of acetes balls in curry processed at $121.2^{0} \mathrm{C}$ for $4 \mathrm{~min}$

\begin{tabular}{|c|c|c|c|c|c|}
\hline Parameter & Sample & (SABWC) & (SABWOC) & (PABWC) & (PABWOC) \\
\hline \multirow[t]{2}{*}{ Moisture } & $\begin{array}{l}\text { Control [Acetes ball in curry product } \\
\text { steamed }\left(0 \mathrm{psi}, 100^{\circ} \mathrm{C}\right) \text { for } 30 \mathrm{~min} \text { ] }\end{array}$ & $\begin{array}{c}64.35^{\mathrm{a}} \pm \\
0.32\end{array}$ & $\begin{array}{l}69.45^{c} \\
\pm 0.29\end{array}$ & $\begin{array}{l}69.98^{c} \\
\pm 0.64\end{array}$ & $\begin{array}{c}70.65^{\mathrm{cd}} \pm \\
0.88\end{array}$ \\
\hline & $\begin{array}{l}\text { Acetes ball in curry product thermally } \\
\text { processed }\left(121.2^{\circ} \mathrm{C}\right)\end{array}$ & $\begin{array}{l}67.55^{\mathrm{b}} \\
\pm 0.29\end{array}$ & $\begin{array}{l}68.50^{c} \\
\pm 0.62\end{array}$ & $\begin{array}{l}71.20^{\mathrm{d}} \\
\pm 0.39\end{array}$ & $\begin{array}{l}69.20^{\mathrm{d}} \\
\pm 0.87\end{array}$ \\
\hline \multirow[t]{2}{*}{ pH } & $\begin{array}{l}\text { Control [Acetes ball in curry product } \\
\text { steamed }\left(0 \mathrm{psi}, 100^{\circ} \mathrm{C}\right) \text { for } 30 \mathrm{~min} \text { ] }\end{array}$ & $\begin{array}{c}6.32^{\mathrm{bc}} \pm \\
0.04\end{array}$ & $6.43^{\mathrm{cd}} \pm 0.03$ & $\begin{array}{c}6.49^{\mathrm{cd}} \pm \\
0.01\end{array}$ & $6.50^{\mathrm{d}} \pm 0.06$ \\
\hline & $\begin{array}{l}\text { Acetes ball in curry product thermally } \\
\text { processed }\left(121.2^{\circ} \mathrm{C}\right)\end{array}$ & $\begin{array}{c}6.01^{\mathrm{a}} \pm \\
0.07\end{array}$ & $6.16^{\mathrm{ab}} \pm 0.09$ & $\begin{array}{c}6.18^{\mathrm{ab}} \pm \\
0.05\end{array}$ & $6.21^{\mathrm{b}} \pm 0.06$ \\
\hline \multirow[t]{2}{*}{ Folding test } & $\begin{array}{l}\text { Control [Acetes ball in curry product } \\
\text { steamed }\left(0 \mathrm{psi}, 100^{\circ} \mathrm{C}\right) \text { for } 30 \mathrm{~min} \text { ] }\end{array}$ & A & A & A & $\mathrm{A}$ \\
\hline & $\begin{array}{l}\text { Acetes ball in curry product thermally } \\
\text { processed }\left(121.2^{0} \mathrm{C}\right)\end{array}$ & B & B & B & A \\
\hline \multirow{2}{*}{$\begin{array}{l}\text { Expressible } \\
\text { water } \\
\text { content }\end{array}$} & $\begin{array}{l}\text { Control [Acetes ball in curry product } \\
\text { steamed }\left(0 \mathrm{psi}, 100^{\circ} \mathrm{C}\right) \text { for } 30 \mathrm{~min} \text { ] }\end{array}$ & $4.11^{\mathrm{a}} \pm 0.06$ & $4.09^{a} \pm 0.58$ & $4.00^{\mathrm{a}} \pm 0.06$ & $3.90^{\mathrm{a}} \pm 0.15$ \\
\hline & $\begin{array}{l}\text { Acetes ball in curry product thermally } \\
\text { processed }\left(121.2^{0} \mathrm{C}\right)\end{array}$ & $9.70^{\mathrm{b}} \pm 0.12$ & $9.60^{\mathrm{b}} \pm 0.29$ & $9.50^{\mathrm{b}} \pm 0.03$ & $4.10^{\mathrm{a}} \pm 0.06$ \\
\hline
\end{tabular}

Note: ab Means in the same row with different superscripts are significantly different $(p<0.05)$

Data expressed as Mean \pm SE $(\mathrm{N}=6)$

Means of all treatments are not significantly different $(\mathrm{p}>0.05)$ by DMRT

Fig.1 Thermal processing of SABWC at $121.2^{0} \mathrm{C}$

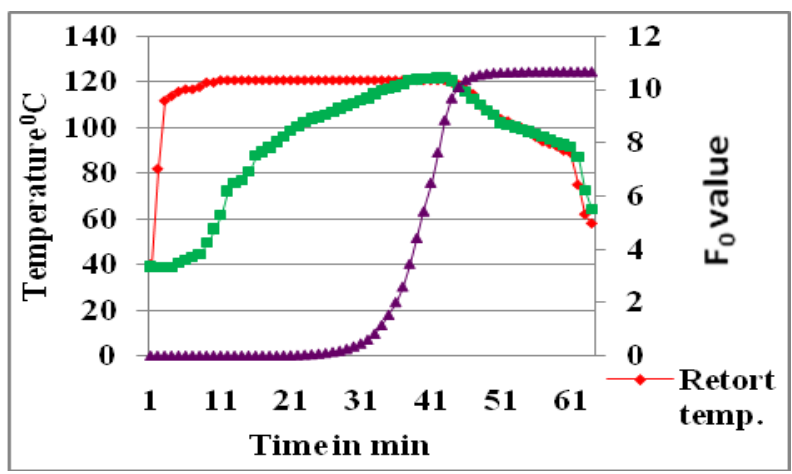

Fig.2 Thermal processing of SABWOC at $121.2^{\circ} \mathrm{C}$

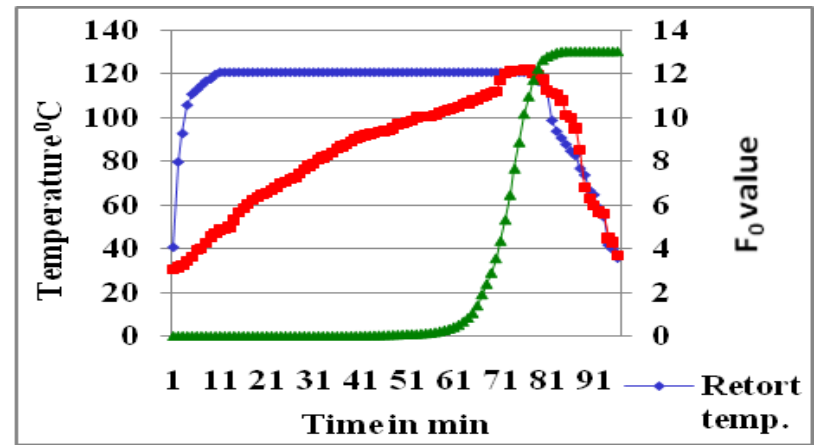


Fig.3 Thermal processing of PABWC at $121.2^{\circ} \mathrm{C}$

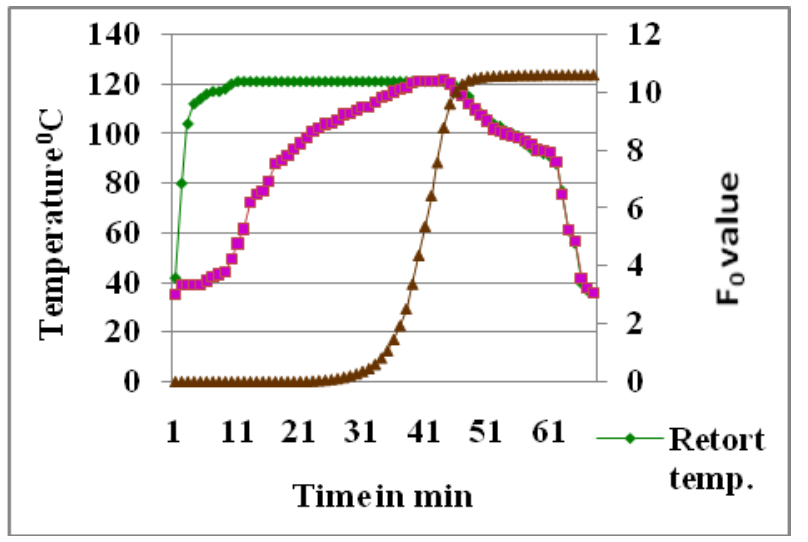

Fig.4 Thermal processing of PABWOC at $121.2^{\circ} \mathrm{C}$

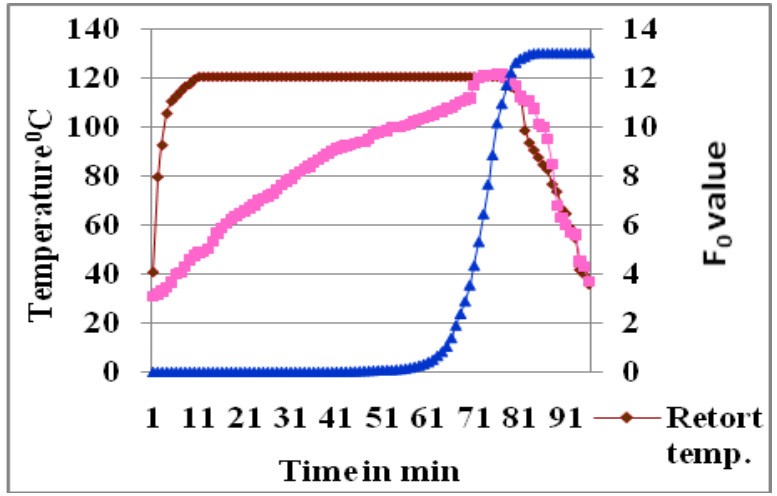

Fig.5 Effect of filling media on the mean organoleptic score of acetes balls in curry processed at $121.2^{\circ} \mathrm{C}$

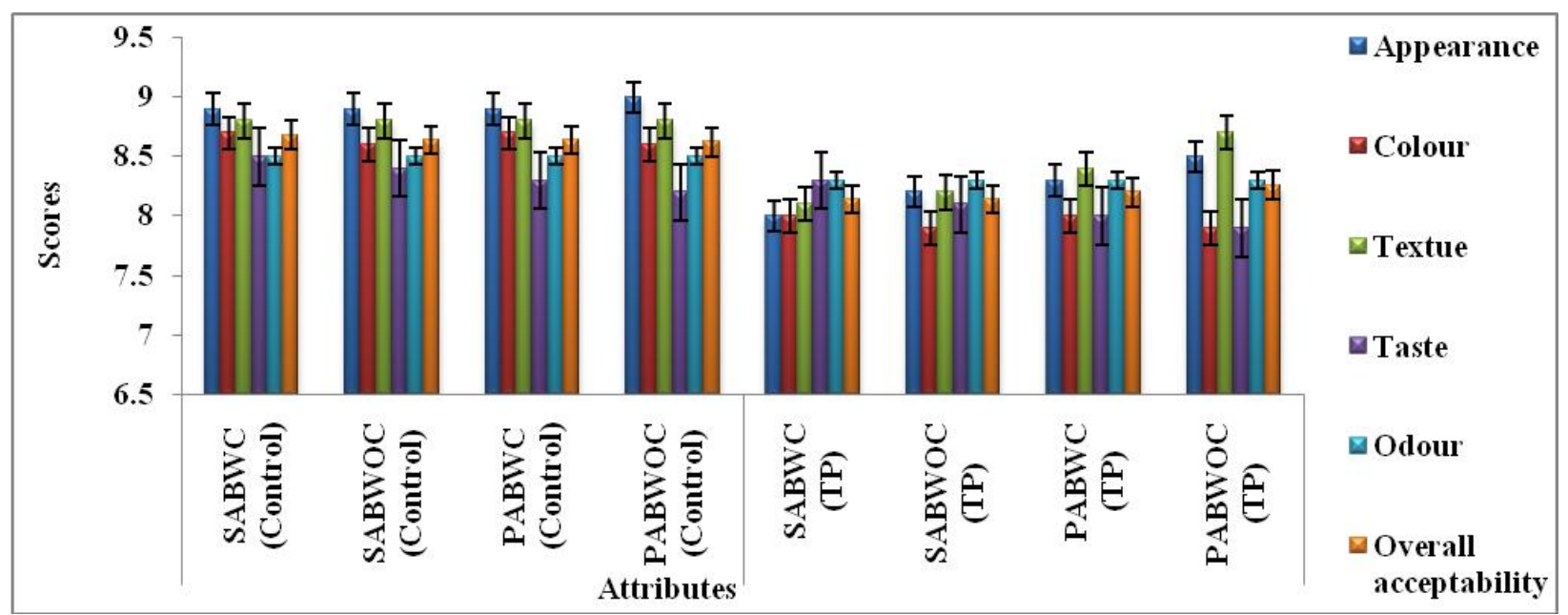

Note: SABWC-Spice mixture acetes ball with curry; SABWOC - Spice mixture acetes ball without curry; PABWCPlain acetes ball with curry; PABWOC - Plain acetes ball without curry 
It was found in the present study that the $\mathrm{pH}$ (Table 4) of plain acetes balls without curry (PABWOC and SABWOC) was higher than other products (PABWC and SABWC). The differences in $\mathrm{pH}$ may be due to the absence of curry as a filling media in PABWOC which increased the relative concentration of acetes meat and surimi, thereby resulting an increase in the moisture content. The $\mathrm{pH}$ of plain acetes balls in PABWC and SABWC products after thermal processing with liquid curry was found to be decreased which may be due to the absorption of organic acids from the curry. Similarly, George et al., (2015b) also observed that the $\mathrm{pH}$ of plain fish ball, subjected to thermal processing without curry was higher.

The moisture content (Table 4) of SABWC and PABWC showed higher values after thermal processing (67.55 and $71.2 \%$ respectively) compared to steamed control (64.35 and $69.98 \%$ respectively). This may be due to the entry of moisture from the curry. However, the moisture content of SABWOC and PABWOC did not show any changes. The moisture content of plain acetes balls was found to be higher as compared to that of curry ingredient. This could be due to the relative increase of acetes meat and surimi as a consequence of non-addition of curry as a filling media and thereby increasing the moisture content in $\mathrm{PABWOC}$ as compared to PABWC, SABWOC and SABWC. Similar trends on the effects of filling media in the moisture content of plain (without ingredient incorporated) fish ball and ingredient incorporated fish ball have been observed by George et al., (2015b).

The expressible water content (Table 4) of SABWC, SABWOC and PABWC showed higher levels of $9.7,9.6$ and $9.5 \%$ after thermal processing from an initial value of 4.11, 4.09 and $4.00 \%$ in control steamed acetes balls. In PABWOC, it did not show any change after thermal processing (4.10) compared to control steamed (3.90) acetes balls. Among the four products, PABWOC held higher folding test grades and lower expressible water percentage indicating improvement in gel strength and texture of acetes balls after thermal processing. Similar trends on the effects of filling media in the expressible water percentage of plain fish ball and ingredient incorporated fish ball have been observed by George et al., (2015b).

The folding test grade (Table 4) of SABWC, SABWOC and PABWC were lower (B, B and $B$ ) after thermal processing from an initial higher folding test grades (A) in control steamed acetes balls. While the folding test grades of PABWOC (A) did not show any changes after thermal processing from control steamed (A) acetes balls. The present investigation indicates that the folding test grade of PABWOC was higher accompanied by lower expressible water percentage as compared to PABWC, SABWOC and SABWC after thermal processing. This may be due to the absorption of moisture and acid from the curry during thermal processing and thereby reducing the gel strength in the latter samples. Similar observations were made by George et al., (2015b) in case of fish ball in curry. Absence of filling media was found to improve the quality and the preference given for the product can be summarized as plain acetes balls without curry (PABWOC) $>$ plain acetes balls with curry (PABWC) $>$ spice mixture acetes balls without curry $($ SABWOC) $>$ spice mixture acetes balls with curry (SABWC).

Based on the above study, it can be concluded that the process period (CUT + PP) was determined to be $42,77,43$ and $84 \mathrm{~min}$ processed at $121.2^{\circ} \mathrm{C}$ for $\mathrm{ABWC}, \mathrm{ABWOC}$, PABWC and PABWOC respectively with the corresponding $\mathrm{F}_{0}$ value of $10.65,12.68,10.61$ and $13.05 \mathrm{~min}$. The plain acetes balls without 
curry (PABWOC) and plain acetes balls with curry (PABWC) had superior texture, folding test grade along with lower expressible water percentage after thermal processing at $121.2^{0} \mathrm{C}$. However, soft texture products like SABWC would fulfill the criteria of suitability to Indian palate.

\section{Acknowledgement}

The authors are thankful to Associate Dean, College of Fisheries, Ratnagiri and ViceChancellor Dr. B. S. Kokan, Krishi Vidyapeeth, Dapoli (India) for their encouragement and providing necessary facilities for the present work.

\section{References}

AOAC (2005). Official Methods of Analysis, $18^{\text {th }}$ edition. Association of Official Analytical Chemists, Washington DC, USA.

Bindu, J., Ravishankar, C. N., Dinesh, K., Mallick, A. K. and Gopal, T. K. S. 2011. Heat penetration characteristics and shelf life of ready to serve mahseer curry in opaque retorable pouches. Fish. Technol., 48(2): 141-148.

Bratt, L. 1995. Heat treatment. In: Footitt, R.J. and Lewis, A.S. (Eds.), The canning of fish and meat. Blackie Academic and Professional, London, 178-211.

CMFRI, 2015.CMFRI Annual Report 20142015, Technical Report. CMFRI, Kochi, $296 \mathrm{pp}$.

Garg, D. K., Kekshmy, Nair M. R., and Prabhu, P. V. 1977. Protein from Jawala prawn (Acetes spp.) and Squilla (Oratosquilla nepa). Fish. Technol., 14(1): 53-56.

George, T. S. 2012. Quality Improvement of Fish Ball in Curry Processed at elevated Temperature. M.F.Sc. thesis submitted to the Dr. Balasaheb Sawant Konkan Krishi Vidyapeeth, Dapoli, Maharashtra, India, 133 pp.
George, T. S., Joshi V. R., Sonavane A. E., Koli J. M. and Kale M. C. 2015a. Heat penetration and organoleptic quality of fish ball in curry processed at elevated temperature. Int. J. Food, Agri. \& Vet. Sci., 5(1):57-65.

George, T. S., Joshi V. R., Sonavane, A. E., Balange A. K. and Vishwasrao V. V. 2015b. Quality improvement of fish ball in curry processed at elevated temperature. Int. J. Agri. Sci. \& Res., 5:33-44.

Gopal, S. T. K., Vijayan, P. K., Balachandran, K. K. and Madhavan, P. 1998. Heat penetration of fish curry in retort pouch. In Advances and Priorities in Fishery Technology. Society of Fisheries Technologists, India, 236-241.

Hamm, R. and Hofman, K. 1965. Changes in the sulphydryl and disulphide groups in beef muscle proteins during heating. Nature, 207: 1269-1271.

IS: 2168. 1971. Specification for Pomfret canned in oil. Indian Standard Institute, New Delhi, India.

ISI. 1975. Guide for sensory evaluation of foods, Part III/Section I, Statistical Analysis of Data (First Revision). Indian Standard Institute. New Delhi, India.

Jagushete, M. 1989. Studies on biology, biochemistry, bacteriology and utilization of Acetes indicus ( $\mathrm{H}$. milne Edwards). M.Sc. Thesis submitted to the Dr. Balasaheb Sawant Konkan Krishi Vidyapeeth, Dapoli, Maharashtra, India, $152 \mathrm{pp}$.

Joshi, V. R. 2014. Report of Pilot scale demonstration of value added products from Acetes using its functional properties. Rajiv Gandhi Science and Technology Commission, Mumbai, Funded project, College of Fisheries, Shirgaon, Ratnagiri. Dr. Balasaheb Sawant Konkan Krishi Vidyapeeth, Dapoli, Maharashtra, India, 78 pp.

Manju, S., Sonaji, E. R., Leema, J., Srinivasa 
Gopal., T. K., Ravishankar, C. N. and Vijayan, P. K. 2004. Heat penetration characteristics and shelf life studies of Seer fish moilee packed in retort pouch. Fish. Technol., 41(1): 37-44.

Mulbagal, A. N., Mahajan, S. N. and Ranade, A. M. 1980. Preparation of edible powder from jawala (Acetes spp.) prawns. Fish. Technol. 1(2): 1- 12.

Nagothkar, N. R. 2013. Development and shelf life of Acetes Sausage. M.F.Sc. Thesis submitted to the Dr. Balasaheb Sawant Konkan Krishi Vidyapeeth, Dapoli, Maharashtra, India, 136 pp.

Nakai, S. and Li-Chan, E. 1988. Hydrophobic Interactions in Food Systems, CRC. Press, Florida. 192 pp. (As quoted by J. Runglerdkriangkrai et al. 2006).

Patil, M. V. 2000. Studies on separation of flesh from Acetes (Javala). M.F.Sc Thesis submitted to Dr. Balasaheb Sawant Konkan Krishi Vidhyapeeth, Maharashtra, India, 56 pp.

Pflug, I. J. and Christensen, R. 1980. Converting an F-value determined on the basis of one Z-value to an F-value determined on the basis of another Zvalue. J. Food Sci., 45(1):30-35.

Rajkumar, V., Dushyanthan, K. and Das, A. K. 2010. Retort pouch processing of Chettinad style goat meat curry - a heritage meat product. J. Food Sci. \& Technol., 47(4):372-379.

Ravishankar, C. N., Bindhu, J. and Srinivasa Gopal, T. K. 2008. Ready to serve Mackerel curry (Goan style) in retortable pouches. Fish Technol., 45(2):171-180.

Runglerd Kriangkrai, J., Banlue, K. and Raksakulthai, N. 2006. High temperature tolerant fish protein gel using transglutaminase and sodium ascorbate Kasetsart J. (Nat Sci.), 40(Suppl.):84-90.

Saralaya, K. V. 1978. Canning of fish sausages. Laboratory manual for courses in canning. College of Fisheries, Mangalore, UAS, Bangalore, $29 \mathrm{pp}$.

Saralaya, K. V. and Bhandary, M. H. 1978. Studies on canning of fish sausages: I. Heat penetration pattern and thermal process requirements. Mysore J. Agric. Sci., 12(3): 479-484.

Shaikh, S. M., Joshi V. R., Pagarkar, A. U., Pai, R. and Balange A. K. 2017. Effect of heat penetration on quality of acetes ball in curry in retort pouch processed at $121.2^{0} \mathrm{C}$ for different durations. J. Exp. Zool. India, 20(1): 605-610.

Shaikh, S. M. 2017. Thermal Processing of Aacetes Balls in Retort Pouch. Ph.D. thesis submitted to Dr. Balasaheb Sawant Konkan Krishi Vidhyapeeth, Maharashtra, India, $238 \mathrm{pp}$.

Sonavane, A. E. 2014. Development of Acetes Sandwich. M.F.Sc. thesis submitted to the Dr. Balasaheb Sawant Konkan Krishi Vidyapeeth, Dapoli, Maharashtra, India, $128 \mathrm{pp}$.

Suzuki, T. K. 1981. Fish and Krill protein \& Processing Technology. Applied science publishers Ltd., Essex, England, 193-252.

Yamazawa, M., Murase, M. and Ichizo, S. 1979. Improvement of the quality of retorted kamaboko. Bull. Jap. Soc. Sci. Fish., 45(2): 187-192.

Zynudheen, A. A., Ninan, G., Sen, A. and Badonia, R. 2005. Ice storage studies of jawala (Acetes spp.) Fish. Technol., 42(2): 231-231.

\section{How to cite this article:}

Shaikh, S. M., V. R. Joshi, A. U. Pagarkar, G. N. Kulkarni and Abhay Kumar. 2020. Effect of Filling Media on the Quality Characteristics of Acetes Balls during Retort Processed. Int.J.Curr.Microbiol.App.Sci. 9(12): 2420-2429. doi: https://doi.org/10.20546/ijcmas.2020.912.287 